

\title{
Going Beyond the Add-and-Stir Critique: Tracing the Hybrid Masculinist Legacies of the Performative State
}

\begin{abstract}
Amya AGARWAL
Associate Postdoctoral Fellow, Centre for Global Cooperation Research, University of Duisburg-Essen
\end{abstract}

To cite this article: Amya Agarwal, "Going Beyond the Add-and-Stir Critique: Tracing the Hybrid Masculinist Legacies of the Performative State", Uluslararasi Miskiler, Vol. 18, No. 70, 2021, pp. 63-83, DOI: $10.33458 /$ uidergisi.985964

To link to this article: https://dx.doi.org/10.33458/uidergisi.985964

Submitted: 10 March 2021

Last Revision: 17 May 2021

Published Online: 13 August 2021

Printed Version: 13 August 2021

\section{Uluslararası İlişkiler Konseyi Derneği | International Relations Council of Turkey \\ Uluslararası İliskiler - Journal of International Relations \\ E-mail : bilgi@uidergisi.com.tr}

All rights of this paper are reserved by the International Relations Council of Turkey. With the exception of academic quotations, no part of this publication may be reproduced, redistributed, sold or transmitted in any form and by any means for public usage without a prior permission from the copyright holder. Any opinions and views expressed in this publication are the author(s)'s and do not reflect those of the Council, editors of the journal, and other authors. 


\title{
Going Beyond the Add-and-Stir Critique: Tracing the Hybrid Masculinist Legacies of the Performative State
}

\author{
Amya AGARWAL \\ Associate Postdoctoral Fellow, Centre for Global Cooperation Research, University of Duisburg-Essen, Germany \\ E-mail: agarwal@gcr21.uni-due.de \\ Orcid: 0000-0002-0527-1016
}

\begin{abstract}
A West-centric knowledge bias has plagued International Relations (IR) for some time, prompting many non-West scholars to develop indigenous knowledge systems. In doing so, there is, however, a risk of both essentialization of certain cultures/histories; and reproducing the hierarchic and exclusionary structure of knowledge production. Moving beyond the add and stir critique style of non-Western approaches to IR, this paper explores the significance of connections and hybrid histories to understand gendered state practices. Through a case study of state performance in Kashmir, the paper traces the hybrid masculinist legacies (colonial, Brahminical and Kshatriya) derived from both Western and non-Western histories.
\end{abstract}

Keywords: Non-Western, International Relations, State, Hybridity, Perfomativity

\section{Ekle-Karıştır Eleştirisinin Ötesine Geçmek: Keşmir'deki Hibrit Edimsel Devletin Erkeklikçi Mirasının İzini Sürmek}

\section{ÖZET}

Batı merkezli bir bilgi yanlılığı, Uluslararası İlişkiler disiplinini bir süredir rahatsız etmiş ve Batılı olmayan birçok akademisyeni yerli bilgi sistemleri geliştirmeye teşvik etmiştir. Ancak bunu yapmanın, hem belirli kültürleri/tarihleri özselleştirme hem de bilgi üretiminin hiyerarşik ve dışlayıcı yapısını yeniden üretme riski bulunmaktadır. Batılı olmayan yaklaşımların Uluslararası İlişkilere yönelttiği ekle-karıștır eleștirisinin tarzının ötesine geçen bu makale, toplumsal cinsiyete dayalı devlet uygulamalarını anlamak için bağlantıların ve melez tarihlerin önemini araştırmaktadır. Keşmir'deki devlet performansına ilişkin bir vaka çalışması aracılığıyla, makale hem Batılı hem de Batılı olmayan tarihlerden türetilen melez erkeksi mirasların (sömürge, Brahmini ve Kshatriya) izini sürmektedir.

Anahtar Kelimeler: Batı Dışı, Uluslararası İlişkiler, Devlet, Hibrit Yapı, Edimlilik

\footnotetext{
The earlier version of this paper was presented during the workshops organized by the World International Studies Committee (WISC) in Goa and Prague in 2017 \& 2018 respectively. I extend my gratitude to fellow participants and colleagues who provided incisive comments and suggestions that helped in improving the paper. In particular, I am grateful to Pinar Bilgin, Zeynep Gulsah Capan, Gunther Hellman, Karen Smith, Stefano Guzzini, Sasikumar S. Sundaram and Vineet Thakur. The subsequent revisions were made during my post-doctoral research fellowship at the Centre for Global Cooperation Research, Germany; and I am thankful to the research team and staff for their constant support, especially to Chirstine Unrau for her valuable comments.
} 


\section{Introduction}

The West-centric bias in the process of knowledge production has been questioned in myriad ways by various inter-disciplinary scholars. ${ }^{1}$ In doing so, several theoretical strategies have been developed to criticize the inherent Eurocentrism in theorizing. Colonial, decolonial and postcolonial theoretical perspectives have emerged to counter the Eurocentric process of knowledge production. These strategies have also travelled to the International Relations (IR) discipline and manifested mainly as the 'non-Western' construction of IR. Efforts entailed in such a construction can be broadly categorised in two main interrelated debates around IR- rewriting the history of IR and problematizing the Euro-centrism of the field. ${ }^{2}$ In an attempt towards a more inclusive 'non-Western' theorization in IR, scholars have directed their attention towards local histories, cultures and political philosophies. Advocates of a non-Western approach argue that the culture and history of non-Western societies are inherently different, and there is ample indigenous material to theorize and develop concepts from their own perspectives.

The problematization of Western dominance/Eurocentrism in the discipline is, no doubt, significant in addressing the power binaries with respect to knowledge production and dissemination. Similarly, the historiographies of IR that attempt to re-write the discipline are also significant in bringing to the fore silenced and omitted histories. However, such attempts to re-write dominant histories, result, on the one hand, in reproducing the dominance of the West; ${ }^{3}$ and on the other hand, they overlook the connectedness between the 'East' and the 'West', as they primarily focus on the 'inherent' difference of local histories and cultures.

Bhambra, for instance, articulates this problem accurately:

"Postcolonial criticism has sought to illuminate these omissions, but it has itself frequently focused on the specificity of what is omitted in the standard accounts, rather than their interconnected and related nature. In other words, it also fails to see the connections as integral to the process previously represented as independent of them."4

1 For example, in his presidential address at the International Studies Association (ISA),2014, Amitav Acharya uses the term 'Global IR' for addressing IR's limits and making the discipline more inclusive. Efforts at making 'Post-Western IR' and 'Non-Western IR' are also visible in the writings of: Naeem Inayatullah and David.L. Blaney, "Knowing Encounters: Beyond Parochialism in International Relations Theory." in Yosef Lapid and Friedrich V. Kratochwil (eds.) The Return of Culture and Identity in IR Theory, Boulder, CO: Lynne Rienner Publishers: 65-84; Giorgio Shani, "Toward a PostWestern IR: The Umma, Khalsa Panth, and Critical lnternational Relations Theory”, International Studies Review,Vol. 10, No. 4, 2008, p. 722-34. Robbie Shilliam, "The Enigmatic Figure of the Non-Western Thinker in International Relations", Antepodium: Online Journal of World Affairs. Victoria University of Wellington, 2009; Mustapha Kamal Pasha, "Western Nihilism and Dialogue: Prelude to an Uncanny Encounter in International Relations", Millennium - Journal of International Studies. Vol. 39, No.3, 2011, p. 683-99. Amitav Acharya and Barry Buzan (eds.) Non-Western International Relations Theory: Perspectives on And Beyond Asia. New York, Routledge, 2010. For more detailed discussion see: Pinar Bilgin, “"Contrapuntal Reading” as a Method, an Ethos and a Metaphor for Global IR”, International Studies Review, No. 18, 2016, p. 134-146.

2 Zeynep Gulsah Capan, Rewriting International Relations: History and Theory Beyond Eurocentrism in Turkey, London and New York, Rowman and Littelfield, 2016.

3 Ibid.

4 Gurminder K Bhambra, "Historical Sociology, International Relations and Connected Histories", Cambridge Review of International Affairs, Vol. 23, No. 1, 2010, p. 127-143. 
Furthermore, the fashioning of non-Western IR theory from the vantage point of a particular country, for instance Chinese IR or Indian IR, may result in the essentialization of certain cultures ${ }^{5}$ and histories, while othering and overlooking the significant hybrid nature of these societies. Also, such studies may inadvertently glorify the local histories and underestimate the exclusionary power hierarchies or colonial reproductions within the non-Western experiences. ${ }^{6}$ Scholars have now offered newer approaches to resolve the problem of the disconnect between 'East' and 'West' found in the pre-dominant postcolonial analyses. Such approaches move beyond the idea of the 'West', or particularly 'Europe' as the centre for events, ideas and concepts; not by simply adding the experiences of the 'East', but by highlighting the interconnectedness between the 'East' and 'West' in the development of international politics. Seth, for instance, argues, "any satisfactory account of the emergence of the modern international system cannot simply chart how an international society that developed in the West radiated outwards, but rather seek to explore the ways in which international society was shaped by interactions between Europe and the colonized." Similarly, the 'connected histories' approach offered by Bhambra is one such significant intervention. She argues, "what is needed is a connected histories approach with a decentred conception of totality; decentred not just spatially, but also conceptually." IR scholars have started reflecting more on how stories are told in IR and the need to go beyond what Capan calls the linear tale of the 'rise of the West', and focus more on placing IR within the framework of interconnectedness. ${ }^{9}$

In this broad context of problematizing the dominance of the West in knowledge production, scholars in India (or working from an Indian vantage point) have also actively worked towards creating a space to incorporate knowledge of indigenous histories, cultures and political philosophies. The initial attempts at questioning the usage of Western standards to judge knowledge produced through non-Western modes of thinking was evident in the early interdisciplinary Indian critique of Enlightenment modernity. The popular work of Ashis Nandy, Rajni Kothari, Dhirubhai Seth, Shiv Vishvanathan and others carried out at the Centre for Studies of Developing Societies (CSDS) are important examples in this direction. ${ }^{10}$ Such critiques are crucial interventions in non-Western theorization. In IR, indigenous scholars have problematized the dominance of the West by incorporating Indian politics, histories and political philosophies relevant in the study of IR. On the one hand, scholars focus on studying the Indian foreign relations, diplomatic histories pertaining to India, nuclear deterrence, and regionalism in South Asia; ${ }^{11}$ on the other hand, they study Indian perspectives on global issues

5 Ferran P. Mena, “The Trap of Diversity: What Constitutes 'Non-Western IR Theory'?”. E-International Relations, 2020. Available at: https://www.e-ir.info/2020/05/08/the-trap-of-diversity-what-constitutes-non-western-ir-theory/ (accessed on 14/04/21).

6 Goldie Osuri and Ather Zia "Kashmir and Palestine: Itineraries of (Anti) colonial Solidarity." Identities: Global Studies in Culture and Power. Vol. 27, No. 3, 2017, p. 339-356.

7 Sanjay Seth, "Post-Colonial Theory and the Critique of International Relations", Millennium: Journal of International Studies, Vol. 40, No. 1, 2011, p. 174.

8 Bhambra, "Historical Sociology, International Relations and Connected Histories"

9 Capan, Rewriting International Relations: History and Theory Beyond Eurocentrism in Turkey.

10 F. Dallmayr, “Global Development? Alternative Voices from Delhi”, Alternatives, Vol. 21, No. 1, 1996, p. 259-282.

11 See, for instance, Priya Chacko, Indian Foreign Policy: The Politics of Postcolonial Identity from 1947-2004. London and New York, Routledge, 2012; Ninan Koshy “Nuclear Weapons and India's Foreign Policy” in Rajen Harshe and K.M. Seethi (eds.), New Delhi, Orient Blackswan, 2005; Pratap Bhanu Mehta "SAARC and the Sovereignty Bargain, Himal South Asian, November-December Issue, 2005, p. 17-21. 
such as international order, international law, and neo-Marxist writings on imperialism and globalization. ${ }^{12}$ The relatively recent genre of Indian IR writings include post-colonial feminist analysis. ${ }^{13}$

A significant approach of theorizing in IR in India has highlighted the relevance of Indian political philosophies. In doing so, scholars go back to the historical Indian political traditions to reveal their significance in existing theories in IR. In adding and stirring of the 'Indian' political philosophies, however, the nuances and complexities of power relations that operate within the post-colonial societies get somewhat overlooked and also result in the essentialization of the Indian culture and history. For instance, attempts are made by IR scholars to rediscover Kautilya to challenge the Western dominance in political realism in IR. Furthermore, Behera argues:

"The impoverishment of traditional IR's political thought becomes further evident on its chosen ground - political realism - that does not recognize or own Indian political philosopher, Kautilya as 'the father of realpolitik'. Kautilya is not taught in any 'principal IR theory courses' and though Arthashastra has much to offer for theorizing IR, the universal applicability of his ideas is not acknowledged - almost universally."14

Shedding light on relevant non-Western political philosophies is no doubt crucial in re-imagining IR as a theoretically inclusive discipline. The problem, however, in simply 'recognizing and owning' or 'acknowledging' Indian political philosophies such as those in Kautilya's Arthashastra is that its contribution in the gendered construction of a national identity gets entirely overshadowed. Arthashastra, as scholars rightly argue, has an implicit presence in Indian politics and can be considered a significant indigenous reference point to study IR in India. ${ }^{15}$ What is more important to recognize, however, is how political philosophies entailed in Arthashastra are drawn by the Indian post-colonial state to enact its own form of colonialism and imperialism.

As an alternative to the add-and-stir critique style of the non-Western approaches in IR, this paper builds upon the 'connected histories' approach; and interjects concepts like 'hybrid performativity' to highlight the interconnectedness of the 'East' and 'West' in the exercise and performance of state power. In doing so, the paper uses the concept of 'hybridity' borrowed from cultural studies that refers to the process of "making of something new through the combination of existing things and patterns." ${ }^{16}$ In the case of the security state in the Kashmir conflict, the paper argues that

12 See, for example, Kanti Bajpai "Indian Conceptions of Order and Justice: Nehruvian, Gandhian, Hindutva and NeoLiberal” in R. Foot, et al (ed.), Order and Justice in International Relations. New York, Oxford University Press, 2003 236-261; Rajen Harshe (ed.)Interpreting Globalisation: Perspectives in International Relations. New Delhi: ICSSR and Rawat Publications, 2004; B.S. Chimni, International Law and World Order: A Critique of Contemporary Approaches. New Delhi: Sage Publications; Achin Vanaik, "Globalization and international relations", in Achin Vanaik (ed.), Globalization and South Asia: Multidimensional Perspectives. New Delhi: Manohar, 2004.

13 Some examples of early post-colonial feminist work in India are: Anuradha Chenoy, Militarism and Women in South Asia, New Delhi, Kali for Women, 2002; Rita Manchanda, Women, War and Peace in South Asia: Beyond Victimhood to Agency, New Delhi, Sage, 2001.

14 Navnita C. Behera, "Reimagining IR in India” International Relations of the Asia Pacific, Vol. 7, 2007, p. 341-368.

15 Surbrata K. Mitra and Michael Liebig, Kautilya's Arthashastra: An Intellectual Portrait: The Classical Roots of Modern Politics in India, Frankfurt, Nomos Verlagsgesellschaft, 2017.

16 Pam Nilan and Carles Feixa. "Introduction: Youth Hybridity and Plural Worlds" in P. Nilan and C. Feixa (eds.) Global Youth? Hybrid Identities, Plural Worlds, Oxon, Routledge, 2006, p. 1-13. The use of hybridity in this paper also draws inspiration from David Duriesmith's application of the concept hybridity in (a very different) context of Indonesian Foreign Fighters. To see more, see David Duriesmith, "Hybrid Warriors and the Formation of New War Masculinities: A Case Study of Indonesian Foreign Fighters”, Stability: International Journal of Security and Development, Vol. 7, No. 1. 2018. 
a combination of colonizer and Brahminical and Kshatriya masculinities form a hybrid form of the performative state in Kashmir. In this regard, the Hindu nationalist discourse and Hindutva masculinity, prevalent in contemporary Indian politics, also draws significantly from the Brahminical and Kshatriya masculine elements of Kautilyan thought. We will assess the gendered nature of the Arthashastra and its continued legacy later in this paper. Instead of 'owning' and simply 'acknowledging' the universal applicability of Kautilya's ideas, we look at how this legacy may be as problematic as the influence of the Enlightenment modernity of the West in the enactment of gendered state practices.

The paper also uses the concept of gender performativity to understand state practices. Judith Butler's idea of gender performativity ${ }^{17}$ is particularly relevant in calling our attention to the performative mode of gender as opposed to only its social construction. Using a gender lens to understand state politics and practices is not a new phenomenon. Several feminists have already showed the gendered nature of sovereign states and their practices. The feminist critique of the realist discourse in IR highlights the gendered nature of states and international politics. ${ }^{18}$ Realism, with its state-centric view of international politics, still remains the pre-dominant lens to view armed conflicts. Kashmir as a conflict, for instance, is mostly viewed through the lens of Pakistan and India, wherein all assumptions and explanations of state politics are primarily based on men's experiences and masculinity. Characteristics of manliness such as toughness, courage, power, physical strength and valour are most valued in conducting international politics. Also, manliness is associated with the use of violence and force, which is applauded in the name of defending one's country. The realist perspective, on the one hand essentializes and reinforces the gender binaries-where 'men are warriors and women are victims' and on the other hand, silences the role and agency of multiple (non-state) stakeholders in conflict-affected contexts. J. Ann Tickner and other feminists have for long, showed through various exploratory lenses how the behaviour of states depends on the experiences of men and hence the ideal of the warrior male can be seen as projected on to the state: "The world that Morgenthau was describing was a masculine world, a world of power and conflict, in which the possibility of war is an ever-present reality. Power and autonomy desirable traits for successful states are also words we associate with masculinity”. ${ }^{19}$

Studying the linkage between masculinity and states is no doubt, a significant link to understand the gender dimension of international politics and make better sense of state violence, gendered power relations and human rights violations. However, apart from the masculine projection of states, IR scholars have also highlighted the performative nature of the sovereign states. Cynthia Weber, for instance, suggests that "sovereign nation states are not pre-given subjects but subjects in process and all subjects in process (be they individual or collective) are the ontological effects of practices which are performatively enacted." ${ }^{20}$ Weber, through the invocation of Butler's concept of performativity emphasizes that instead of accepting the universal masculine/feminine codings of the sex and gender of sovereign nation states, it is important to investigate "how various, particular historically bounded

17 Judith Butler, Excitable Speech: A Politics of Performative, New York, Routledge, 1997.

18 See, for example, V. Spike Peterson, Gendered States: Feminist Revisions of International Relations Theory, Lynne Rienner, 1992.

19 J. Ann Tickner, 'Rethinking the State in International Relations: A Personal Reflection' in Swati Parashar et al (eds.) Revisiting Gendered States: Feminist Imaginings of the State in International Relations, New York, Oxford University Press, 2018.

20 Cynthia Weber, “Performative States”, Millennium: Journal of International Studies, Vol. 27, No. 1, 1998, p. 77-95. 
sex and gender codings participate in affecting the state and sovereignty." ${ }^{21}$ In the same spirit, recent feminist analyses also move beyond the critique of the state and highlight the importance of theorizing the gendered nature of state:

"We argue that feminists IR scholars have been more engaged with critiquing the state than in theorizing states and understanding their gendered origins. Most feminist critiques of the state have addressed the exclusion and marginalization of women and gender minorities, its inherent inequalities, patriarchal character and violence. We, ask in this volume to what extent the state speaks a gendered language, behaves like a patriarch and enables gendered politics, citizenship and policies at different levels."22

Drawing inspiration from the above work and Weber's analysis of the performative nature of states, this paper also assesses how certain gender codings are implicit and affect state performance, rather than beginning with the critique of the projection of masculine state. In doing so, the paper moves beyond the projection of state masculinity as a product of colonialism/Westphalian conception, focusing on the hybrid nature of its performativity to understand the gendered origins.

Ashis Nandy has argued that the rigid dichotomy between masculinity and femininity was a product of the gender ideologies of the post-Enlightenment West and was manifested in the hypermasculinity of British imperial ideology in India. ${ }^{23}$ This paper, however, differs from Nandy's stand and attempts to show that 'hypermasculine' elements of the contemporary Indian state are not only a legacy of the British but also reflected in the ancient traditions of Indian political thought. Through her study of masculinity during colonial India, Sinha arrives at a particularly significant meaning of masculinity, which "is derived from the specific power relations that it is deployed to reproduce in particular historical contexts." ${ }^{24}$ This paper also argues that masculinity is not a concept that can be transplanted from the West, in Sinha's words, "it has no a priori context or origin" but rather reproduces itself through social practices differently in different historical contexts. ${ }^{25}$

We will see in the following part of the paper how the performativity of the security state in Kashmir is affected by two significant masculinist legacies. First, the masculine ideals (purusha) of political authority found in Kautilya's Arthashastra, which to a great extent explains the Hindu masculinities and second, the colonial masculinity inherited by the Indian state along with its post-colonial anxieties. We explore these historical factors and their implicit presence in the functioning of the state. Through a gender reading of Kautilya's Arthashastra, secondary literature on colonial masculinity, and an ethnographic study conducted in Kashmir, this paper also attempts to expand the methodological nuance by incorporating sociological, anthropological and ethnographic insights. Before we begin the analysis of the inherited masculinities of the state, I briefly illustrate my research method as well as historical background to the Kashmir conflict.

21 Ibid.

22 Swati Parashar, J. Ann Tickner and Jacqui True (eds.) Revisiting Gendered States: Feminist Imaginings of the State in International Relations, New York, Oxford University Press, 2018.

23 Ashis Nandy, The Intimate Enemy: Loss and Recovery of the Self Under Colonialism. New Delhi, Oxford University Press, 1983.

24 Mrinalini Sinha, 'Giving Masculinity a History: Some Contributions From the Historiography of Colonial India'. Gender and History. Vol. 11, No. 3. November, 1999, p. 445-460.

25 Ibid. 


\section{Method}

The research and analysis entailed in this paper builds on the existing literature on multiple masculinities in Indian context to offer a gender reading of Kautilya's arthashastra. The research also includes an ethnographic study conducted in the Kashmir conflict between 2013-2016 for the author's PhD field research. For this paper, information on the training methods, slogans and counterinsurgency practices of the state is included in order to understand the masculine basis of state practices and performativity. The data was collected from different army camps in Kashmir and interviews with army personnel and Kashmiri locals from different districts such as Budgam, Anantnag, Shopian, Palwama, Baramulla, Sopore, and Srinagar. The slogans, graffiti and engravings on the hills, training videos, and Bollywood representations were also studied in order to understand the gendered state practices. The interviewees were selected on a random basis through government lists and through leads provided by previous respondents.

It is also important to briefly mention a note on author's positionality. As Henry, Highate and Sanghera rightly argue, the political locatedness of the researcher needs to be continually reflected upon by researchers, not as an exercise in navel-gazing, but as the basis of transformative politics. ${ }^{26}$ Researchers sometimes assume that their position does not make much of a difference over the information gathered. However, their positionalities play a huge role in influencing the ways in which interviewees participate and the research is affected. While conducting research, the author often reflected on her positionality as a non-Kashmiri (outsider) Indian woman who came from Delhi. While the author's identity was not much of a problem during the interviews with Indian army personnel, but due to the volatile nature of the conflict and the discontent against the Indian state, it required effort to gain the trust of local interviewees. ${ }^{27}$

It may also be useful to state a word about the choice of the two distinct historical factors in the study of the gendered security state in the Kashmir conflict. Firstly, the histories of masculinity were chosen based on their implicit presence in contemporary state practices. How the state exercises power through counter-insurgency practices in the conflict and the strategies it uses has a strong reflection of the Brahminical, Kshatriya and colonial forms of masculinity - thus resulting in a hybrid form of state masculinity. So, histories of masculinities are not chosen randomly but instead because of their presence in the state performances. Secondly, the combination of both the Western and non-Western masculinities to study state practices is an important theoretical intervention in order to complexify the non-Western approaches in studying conflicts. Finally, the incorporation of a critical masculinities' perspective provides a more nuanced and intersectional understanding of power relations embedded in state practices.

For the section on the Brahminical and Kshatriya masculinities, I use Patrick Olivelle's translated version of Kautilya's Arthashastra - King, Governance and Law in Ancient India: Kautilya's Arthashastra-A New Annotated Translation ${ }^{28}$ for undertaking a gender reading of the text. In addition,

26 Marsha Henry et al. "Positionality and Power: The Politics of Peacekeeping Research." International Peacekeeping. Vol. 16, No.4, 2009, p. 467-482.

27 For the same, the author is thankful to her Kashmiri research collaborators for helping build the trust among the interviewed locals.

28 Patrick Olivelle, King, Governance and Law in Ancient India: Kautilya's Arthashastra-A New Annotated Translation, New York, Oxford University Press, 2013. 
Uma Chakravarti's study of the gender dimension of Kautilyan thought has provided foundational understanding for this research. ${ }^{29}$

\section{Kashmir Conflict: Short Background}

The ongoing conflict in Kashmir dates to the partition of the Indian subcontinent into India and Pakistan in 1947. Before the partition, Kashmir was a princely state with a Muslim majority ruled by a Hindu king - Maharaja Hari Singh. The princely states of British India were given the choice to accede to either India or Pakistan under the Indian Independence Act of $18^{\text {th }}$ July 1947. Forced by a Pakistan-backed tribal militia's attack, the Maharaja decided to accede to India despite contestation and resistance from within Kashmir. The princely state that acceded to India included three major provinces: Jammu, which had a Hindu majority, Kashmir valley with a Muslim majority and Ladakh, which was Buddhist-dominated. With a failed promise of a plebiscite to confirm the accession which was made by Jawaharlal Nehru and accepted by the United Nations (in UN resolution no. 47), three generations of Kashmiri Muslims have felt betrayed and continue to feel discontent. Three wars were fought between India and Pakistan over Kashmir in 1947, 1965 and 1999..$^{30}$ The governments at the centre and in the J\&K state have had challenging relationships, despite its special status granted through the Article 370 in the Indian constitution, which was abrogated by the current ruling government in India in August 2019.

The resistance in the Kashmir valley has taken different forms since India's independence, but peaked in the late 1980s, when it turned into an armed rebellion against the Indian state. This was a result of resentment of the youth against Indian state's failure to conduct plebiscite and its rigging of elections in 1987, as well as inspiration from the success of revolutionary movements around the world. Many young men crossed the Indian border into Pakistan-administered Kashmir for arms training. Local Kashmiris wholeheartedly supported the growing militancy movement and provided myriad help to the militants. The state, on the other hand, adopted tough counter-insurgency measures to quell dissent. Over the years, there was an enormous increase in the cases of human rights violations in the form of killings, enforced disappearances and mass rapes. Extraordinary laws such as the Armed Forces Special Powers' Act (AFSPA) gave further powers to the Indian armed forces in Kashmir to shoot any person on the basis of mere suspicion. Gradually, the widespread support for the militants started shrinking from the late 1990s into early 2000s. Over time, militant groups were also turning guns on each other, and the masses began to grow disillusioned with an increasingly fragmented militancy. The love and respect that militancy had gained in the initial phase was lost, and what followed was a reign of terror and diktats from the militant groups, especially those involving foreign militants. ${ }^{31}$

The year 2008 marked the renewal of Kashmir's resistance movement, when the Indian government reached an agreement with the J\&K state to transfer 99 acres of forest land to the Amarnath Shrine Board, which facilitates the religious pilgrimage from mainland India to the Amarnath cave. People in Kashmir considered this decision a massive violation of Article $35 \mathrm{~A}$ and 370 that granted

29 Uma Chakravarti, "Saffronising the Past: Of Myths, Histories and Right Wing Agendas" Economic and Political Weekly. Vol. 33, No. 5, 1998, p. 225-232.

30 Andrew Whitehead, A Mission in Kashmir. New Delhi, Penguin, 2007; M.J.Akbar, Kashmir: Behind the Vale. New Delhi, Roli Books Pvt. Ltd, 2002; Wajahat Habibullah, My Kashmir: Conflict and the Prospects of Enduring Peace. Washington: United States Institute of Peace Press, 2008; C. Dasgupta, War and Diplomacy in Kashmir: 1947-48. Delhi, Sage, 2002.

31 Harinder Baweja, "Kashmir: A Calculated Gamble”, India Today, 1992. 
autonomy to the state. A large number of people gathered for a rally and protested against this decision. ${ }^{32}$ Slogans like 'Go Back India Go Back' were heard and stones were pelted by young teenagers towards army vehicles. Indian armed forces used pellet guns as weapons to suppress this resistance.

In 2010, the killing of a 17-year-old boy Tufail Mattoo, who had been caught in a clash between the stone pelters and police, ignited people's anger and gave rise to a fierce rebellion. Young boys and girls came on the streets to confront and pelt stones at the Indian Army. Several young boys suffered pellet injuries and many decided to join militancy. Kashmir once again saw a new form of indigenous militancy comprising of young men who posted pictures on social media platforms such as Facebook and became popular heroes. Women approved of and provided wholehearted support to the aspiring militants. In 2016, the leader of the new militancy, Burhan Wani, was killed by the Indian armed forces, which led to further protests. Men and women gathered in large numbers at his funeral procession. Women sang songs of glory, praise and freedom. The Indian state adopted repressive and violent methods to quell the growing dissent. The Indian state also developed strategic partnerships with countries like Israel to enhance its counter-insurgency operations. .

Kashmiri politics took a further new turn with the abrogation of Article 370 of the Indian constitution, which had granted a special status to the J\&K state by the Indian government in August 2019. A curfew was imposed, Kashmiri political leaders were placed under house arrest and internet services were cut off for months. ${ }^{33}$ The Indian state claims that the decision will improve the condition of Kashmir through a focus on development, but a positive change is not visible so far.

\section{The Hybrid-Performative State in Kashmir: Brahminical, Kshtariya, Colonial Masculinities and Post-Colonial Anxieties}

The practices of the Indian state in Kashmir throughout the post-colonial period provide a significant case for studying the hybridity of the exercise of state power. We will, however, primarily focus on the period from 2008 to understand how security-state practices in Kashmir reflect a nexus of Brahminical, Kshatriya and colonial masculinities. Also, the existing dominance of the Hindu nationalist discourse in contemporary Indian politics has resulted in serious implications for the valley, which has a majority of Muslim inhabitants. Advocates of Hindutva view the Kashmiri struggle for self-determination as a threat to the sovereignty and integrity of the Hindu nation. ${ }^{34}$ The heavy militarization along with the surge of Hindu nationalist sentiments in India have further added to the hostile situation in Kashmir. Counter-insurgency operations have also been influenced, to some extent, by the contemporary political context in India. In the following sections, the paper attempts to unpack the diverse masculinities associated with the state performance.

\section{Colonial Underpinnings and Post-Colonial Anxieties in State Performance}

The colonial past of India, no doubt, created a significant foundation for the reinforcement of power hierarchies and structural inequalities. Its legacies continue to be upheld and wielded in different ways.

32 "Land transfer to Hindu Site Inflames Kashmir's Musims", New York Times, June 28, 2008.

33 Ibid.

34 Swati Parashar, "Competing Masculinities, Militarization and the Conflict in Kashmir". International Feminist Journal of Politics (IFJP). Vol. 20, No. 4, 2018, p. 663-665. 
As mentioned before, different strands of scholarship, commonly understood as postcolonial and decolonial, while differing from colonialism, continue to examine present forms of coloniality through West/Non-West, Europe/Non Europe, and Global North/Global South binaries. This scholarship is no doubt important to highlight the indigenous experiences, however, the ways in which post-colonial states reproduce colonial practices that are exclusionary and discriminatory is often overlooked. As stated earlier, simply adding non-Western and indigenous histories as a way to critique the colonial and post-Enlightenment West, results in glorifying certain histories and cultures that have been highly gendered and violent.

In the context of conflict-affected regions, the concept of coloniality is particularly relevant. The sovereign state's violence and related human rights violations can be better understood through the lens of coloniality. To illustrate this point, there is emerging scholarship that studies the Kashmir conflict through the settler-colonial framework, as in other conflict affected contexts such as Palestine. They argue that state's sovereignty and violence is comparable to that of colonizers. When we further incorporate a masculinities lens to understand coloniality of the state in conflicts, we find a road block. Existing postcolonial studies often describe the state performativity in Kashmir through binaries of the 'hypermasculine' colonizer and 'effeminate' colonized. Such references can be traced to the work of sociologists who studied colonial masculinities. For instance, Edward Said's argument of the eroticization of the Orient as the female and feminization of the colonized male in relation to the colonizing male. ${ }^{35}$ More specifically in India, Sara Suleri in The Rhetoric of English India shows the complex dynamics of what she calls 'deferred homosexual decorum' where she complicates the discourse of heterosexual rape symbolized by the colonizer male raping the colonized female. ${ }^{36}$ She instead describes the homosocial eroticism between the hyper masculinized British men and the effeminate Indian men. Similarly, Nandy has argued that the rigid dichotomy between masculinity and femininity was a product of the gender ideologies of the post-Enlightenment West and manifested in the hypermasculinity of British imperial ideology in India. ${ }^{37}$

Although the colonizer masculinities are significantly reproduced in the Kashmir conflict, there are some problems with the above conceptualizations. Firstly, the binaries of 'hypermasculine' and 'effeminate' essentialize male and female representations, in which men's experiences of vulnerability and women's choices of violence are implied as exceptions to gender norms. Scholars of critical masculinities studies have problematized the usage of terminologies such as 'emasculation', 'feminization' and 'effeminate' for similar reasons. ${ }^{38}$ Secondly, the masculine performativity of post-colonial nation states is not only derived from British rule. Instead, it is important to extend and complexify our understanding of coloniality and state's performances in conflict situations and, in doing so, build our understanding through hybrid and overlapping masculinities. While the exercise of English colonizer

35 Edward Said, Orientalism, New York, Vintage Books, 1978.

36 Sara Suleri, The Rhetoric of English India, Chicago, University of Chicago Press, 1992

37 Ashis Nandy, The Intimate Enemy: Loss and Recovery of the Self Under Colonialism. New Delhi, Oxford University Press, 1983.

38 Heleen Touquet, and Ellen Gorris, "Out of the Shadows? The Inclusion of Men and Boys in Conceptualizations of Wartime Sexual Violence'. Reproductive Health Matters. Vol. 24, no, 47, 2016, p. 36-46; Philipp Schulz, Male Survivors of Wartime Sexual Violence: Perspectives From Northern Uganda. Oakland, California: University of California Press, 2020; Sandesh Sivakumaran, "Sexual Violence against Men in Armed Conflict”. European Journal of International Law. Vol. 18, No. 2, 2007, p. 253-276. 
masculinity is one form, it is not the only one inherited by the Indian state. Also, English masculinity in India was shaped by various other earlier forms of power.

O'Hanlon, for instance, in her study of the eighteenth century North-Indian politics, places emphasis on the fact that British colonial culture was certainly not the first to deploy masculinity as a form of power and may have built on earlier such deployments of masculinity. Here, she rightly points out that the masculinity of Hindu or Muslim, Maratha, Rajput or Pathan had to compete within a broadly shared code of martial imperial masculinity. However, going further, the colonizer's masculinity of British men was itself shaped by the entanglements of such multiple masculinities. These arguments responds to Nandy's claim that martial traditions were a relatively minor part of the precolonial Indian culture. ${ }^{39}$ Similarly, Indira Chowdhury-Sengupta examines the redemptive pedagogy of manliness in Bengal, where she discusses the creation and re-creation of masculinity in a network of institutions from the Hindu mela of the 1870s to popular songs of the Swadeshi movement of $1905 .{ }^{40}$

Post-independence nation-building was based on what Parashar calls postcolonial anxieties and a crisis of masculinity:

"India's postcolonial anxiety is (re)produced in popular histories of colonialism and its legacy in public discourses, relived through everyday collective memories. The crisis of masculinity, on the other hand, is manifested in the rejection of a feminized/androgynous/soft Indian state in the post-independence Gandhi-Nehru era (1947-64), and the invocation of the great ancient pre-Islamic Indian past, when Hindu men shaped their culture and destiny alongside exercising patriarchal control over "their" women."

Scholars have contended that the invocation of the great Hindu past and the othering of the Islamic presence are integral to the post-colonial national building. ${ }^{42}$ In the same way, masculine attributes and performances of the post-colonial state in Kashmir cannot be understood in isolation from the construction of Hindu nationalist discourse. In contemporary Indian politics, the assertion of a new Hindu identity as Anand argues, conflates nationalism with masculinity and violence. The Hindutva masculinity is built upon the invocation of a fictional inimical figure of the Muslim 'other', which is 'a mix of negative images of Islam's history, physicality and culture.'43

When Hindu nationalist politics are embraced by the state, it can prove to be lethal for nonHindu minorities. ${ }^{44}$ This is because, as a state practice, Hindutva gained legitimacy and is naturalised as a norm. In this context, the masculinized Hindu nationalist discourse has serious implications in the Muslim-majority Kashmir valley. Advocates of Hindutva view the Kashmiri struggle for self-determination as a threat to the sovereignty and integrity of the Hindu nation. ${ }^{45}$ The counter-insurgen-

39 Rosalind O’Hanlon, “Issues of Masculinity in North Indian History: The Bangash Nawabs of Farrukkha”. Indian Journal of Gender Studies, Vol. 4, No. 4, 1997, p. 1-19.

40 Indira Chowdhury-Sengupta, "The Effeminate and the Masculine: Nationalism and the Concept of Race in Colonial Bengal," in Peter Robb (ed)., The Concept of Race in South Asia. New Delhi: Oxford University Press, 1995.

41 Swati Parashar, "Competing Masculinities, Militarization and the Conflict in Kashmir"

42 Dibyesh Anand, "Anxious Sexualities: Masculinities, Nationalism and Violence". The British Journal of Politics and International Relations. Vol. 9, No. 2, 2007. Available at: https://journals.sagepub.com/doi/full/10.1111/j.1467856x.2007.00282.x.

43 Ibid.

44 Ibid.

45 Parashar, "Competing Masculinities, Militarization and the Conflict in Kashmir". 
cy operations are also to some extent influenced by the contemporary right-wing political context in mainland India. The mimicry of the colonizer masculinity is visible in the state violence and the strong control over the territoriality of Kashmir. The abrogation of Article 370 in August 2019, that granted special status and territorial autonomy to Kashmir signals, as Osuri and Zia mention "India's emergence as a settler-colonial state for the Kashmiris" ${ }^{\prime 6}$. The ways in which the Indian state enacts its politics in the Kashmir conflict finds overlaps between Hindutva and colonial masculinities. To understand how Hindu masculinity is wielded by the state, it is important to first understand the significant historical legacy and influence that helped formed the Hindutva masculinity.

\section{The Masculinity(ies) of Political Authority in Kautilya's Arthashastra}

The Arthashastra is an early Indian Sanskrit treatise that serves as a guide to statecraft, military strategy, societal relations and economic policy. Kautilya also sometimes called Chanakya or Vishnugupta is credited as the author. Kautilya's Arthashastra covers political philosophy and theory, governance, public administration, economics, law, diplomacy and foreign policy, intelligence and military affairs in 15 'books' subdivided into 150 chapters. ${ }^{47}$ After its rediscovery by R. Shamashasty in 1905, studies have emerged showing its relevance in political discourse; and parallels between Kautilya's political thinking with Machiavelli, especially with regard to political realism are drawn frequently.

The three main aspects of Arthashastra are: how a king should govern; enhance economic activities; and foster relations with neighbouring states in such a way to increase the king's own power and wealth, clearly laying out the objective of the text which is to provide a blue print for the political authority in order to achieve political and economic success, irrespective of the circumstances. While the pursuit of power is regarded as the ultimate task of the king and the entire Kautilyan thought is a male-dominated venture, the masculinity discourse in Arthashastra forms a nexus between two forms of masculinities: Brahmanincal and Kshatriya.

The might of the Kshatriya masculinity is manifested in physical prowess. Bravery and virility are seen as the dual characteristics. In contrast and unlike, the conventional masculine attributes of is political authority found in historical writings of the West, Brahmanical masculinity found in Arthashastra is attained through a complete control of the five senses. Indeed, abstinence is considered the highest form of strength (viriya). Brahminical masculinity, with its emphasis on knowledge as power, gives paramount importance to intellectual pursuits. Here, celibacy is an important component of manhood, but unlike the celibacy of Buddhist monks that leads to 'escapism and emasculation', retention of semen can lead to achieving high levels of tejas - "intellectual prowess, mental and physical vigour and spiritual energy." Uma Chakravarti highlighted the nuances of the Hindutva politics in mid-1980s through a discussion on the tele-series on Chanakya (Kautilya). ${ }^{48}$ Describing the maleness of the Chanakayan venture, she argued that the containment of male sexuality and its subsequent deployment occupies a key place in his political agenda. In the same light, she laid out four categories of men that revolve around Kautilyan thought: the first is the young male, a 'Brahamacharya', engaged in vigorous physical and mental training; the second is of the older renunciate male who is the protagonist himself. Both the 'brahmacharya' and the mentor or 'shikshak' are celibate males. In contrast, the third category is of debauched and over

46 Osuri and Zia "Kashmir and Palestine: Itineraries of (Anti) colonial Solidarity"

47 Michael Liebig, "Kautilya's Relevance for India Today” India Quarterly: A Journal of Indian Affairs, Vol. 69, No. 2, 2013, p. 99-116.

48 Chakravarti, "Saffronising the Past: Of Myths, Histories and Right Wing Agendas." 
sensuous males, whose masculinity has been crippled due to their overindulgent sexuality; and the final category is that of the grahastha, comprising all patriarchs of Brahmana households who are located in the world of administration and governance, some are employed by the king as advisors, ministers or councillors - "their relationship to sexuality is highly structured." 49

According to Chakravarti, masculinity is handled in dichotomous ways in Chanakya. The first is equated with physical strength, heroic valour and patriotism, which together constitute the male virility; and on the other, it is equated with cowardice, treachery, debauchery over-gratification of the sexual drive and emasculation or the loss of male sexual drive. A reading of Arthashastra using a gender lens reveals a clear and elaborate distinction between what characteristics constitute masculinity and what lead to emasculation. ${ }^{50}$

Kautilyan thought in foreign affairs, the theory of Mandala, which is the sphere or circle of influence (interests, ambitions, enterprise), also offers significant insight into how Brahmanical and Kshatriya masculinity are projected onto the state. As BK Sarkar points out, the theory of Mandala is necessarily the theory of Vijigeeso (aspirant to conquest). Here, it is important to note that conquest necessarily implies expansion, which is a masculine attribute and characterised by an "upward striving." Sarkar remarks: "the doctrine becomes necessarily a spur to the struggle for existence, self-assertion and world domination." ${ }^{11}$ The survival, pursuit of power and ambition to dominate the world all embody a Kshatriya masculinity. The embodiment is successful when the king or the vijigeeso establishes himself in the nabhi (or the centre of gravity) of the system. The full sphere is a circle of states including his allies, enemies and neutrals.

Similar to the masculinist assumptions of realist thought in IR borrowed from Western political theorists point towards the inevitability of war in Kautilya. He argues that the logic of Matsyanyaya (anarchy which leads to eternally warring states) turns the world into a theatre of war. There is always a hypothetical tug of war between the vijigeeso and the ari (the enemy); the other two members of the quadrivium (madhyama and the udaseena) are always counted to complete the logic of inevitability of clash and conflict. The Kshatriya aspects of masculinity are further evident in the Mandala theory, when Kautilya instructs the vijigeeso to remain prepared - "be ever ready with a danda" and "should always have one's might in evidence and policies well-guarded, as well as be ever on the look-out for the enemy's holes." 52

The danda is referred to the army or military, which is one of the seven elements of the state in the Saptanga theory and protects the state from external and internal aggression. Danda is a significant indicator of the masculinist underpinnings of the political authority in Kautilya's thought, because it entails two important aspects- first it acts as an important tool in the hands of the king to perform the role of a 'protector' which gives it a status of power, helps in establishing his hegemonic masculinity and renders the 'praja' or the people as weak and in need of protection. Secondly, it also equips the king to punish people with 'anarchic tendencies', meaning any potential threat to disrupt the social and political order.

49 Ibid.

50 Ibid.

51 Benoy K. Sarkar, “The Hindu Theory of International Relations”, American Political Science Association, Vol. 13, No. 3, August 1919, p. 400-414.

52 Patrick Olivelle, King, Governance and Law in Ancient India: Kautilya's Arthashastra-A New Annotated Translation. 
While the survival, conquest, expansion and violent punishment together constitute Kshatriya masculinity, Kautilya also stresses the importance of the intellectual sharpness of the king to be able to manipulate circumstances in order to maintain his sovereignty in domestic and international affairs. In this regard, Kautilya advises the king to use the four clever upaayas (remedies): conciliation (sama), giving presents (dana), causing dissensions (bheda) and war of punishment (danda), in order to turn any situation in his favour. He also emphasizes the importance of trickery and deceit through employing internal (Abhyantar) and external (Baahya) spies. The five institutions of espionage according to him are working under the guise of a fraudulent disciple (Kappatika, chhatra), a sham ascetic who has fallen from the real duties of asceticism (Udaasitha), a householder spy (grihapatika), a merchant spy (vaidehaka), and a spy under the guise of an ascetic practicing austerities. There are four wandering spies, also regarded important: classmate spies or spies learning by social intercourse (satri), fireband of fiery spies (tikshna), poisoners who are very cruel (Rasad), and a woman ascetic (bhikshuki).

Apart from manipulation techniques, another important aspect of the glorification of masculinity in Arthashastra is the devaluing of women. There is no striking presence of women in Arthashastra in comparison to the "heroic agenda allotted to the men." 53 Their agency as mothers is also denied. Women's role is mainly reduced to that of reproduction, and marriages in Kautilyan thought are only alliances that serve political goals. The manner in which a sex-worker is required to meet patriotic goals clearly suggests free utilization of female sexuality to meet 'just ends'. Courtesans, actresses, bhikshuki gather crucial information and counter moves are prepared accordingly. Similarly, the 'vishkanya' uses her body to poison the last of the enemies of Chandragupta in the Chanakya tele series. In this regard, Chakravarti correctly points out that "the prostitute's sexuality is the structural counterpart of the celibacy in the political agenda of redeeming the nation's future." ${ }^{34}$ The kuta-niti of the prostitute matches the kuta-niti of Chanakya: it is a means by which the nationalists can effectively counter the kuta-niti of treacherous men who betray the nation.

Thus, the stress upon the highest prowess attained by men through celibacy is defined against the seductive sexuality of the prostitute implying the objectification and devaluing of femininity in order to achieve masculinity.

The Hindu masculinity, with both Brahminical and Kshatriya elements (celibacy, discipline and physical training) derived from Kautilyan thought, also seems to be integral in the formation of the Hindu nationalism, embodied within various political and cultural organizations, which are together called the Sangh Parivar (Sangh family). Bhartiya Janata Party (BJP) is the main political party associated with it, Rashtriya Swayamsevak Sangh (RSS) [National Volunteer Organization] provides the ideological foundation, and other members include Vishwa Hindu Parishad (VHP), Bajrang Dal, Rashtriya Sevika Samiti and Durga Vahini. The RSS entails military practices and training of young men, who wear Khaki shorts and perform physical exercises and martial training with long sticks (lathis). They recite their oath of commitment towards the regeneration of a pure Hindu nation, standing in rows while their hands are stretched in front of their chest. Another Hindutva promoting regional party 'Shiv Sena' (Maratha warrior king Shivaji’s army) also adopts military practices and in

53 Chakravarti, "Saffronising the Past: Of Myths, Histories and Right Wing Agendas."

54 Ibid. 
emulation of the supposed militant Muslim practices. Hansen shows in his detailed exploration of the recuperation of masculinity (Hindu potency) that a common theme in both these organizations is achieved through the othering of Muslims and the physical activism along with discipline. ${ }^{55}$ The Hindu nationalist discourse is also based on a gendered representation of the nation as Hindu mother - an object of worship, reverence and protection - clearly articulated in Bankim Chattopadhyay image of Bharat mata (Mother India).

\section{Relevance of Kautilyan Thought in the Gendered State Practices}

The relevance of realist Kautilyan thought in modern Indian politics cannot be overlooked. Michael Liebig, for instance, in his research on the relevance of Kautilya in modern Indian politics, draws attention to its manifest and latent presence in contemporary political thought in India. The first indicator of the manifest presence, as Mitra and Liebig mention, is visible in historical accounts of Indian leaders engaging with Kautilyan thought, such as Nehru reading Kautilya in the prison in $1930 .^{56}$ The second indicator is the 'Chanakya metaphor', which is an explicit yet non-discursive reference to Kautilya: a cunning statesman who gets things done whatever it takes. The third indicator is the symbolic presence in the naming of streets, private institutes, and businesses. Lastly, it is visible in electronic and print media in the form of TV series, comics, and guide books.

The latent presence of Kautilya, as Mitra and Liebig argue, is the reference to Kautilyan thought without explicitly mentioning or thinking of him. These have been incorporated during the socialization process and have had a great role to play in the present patterns of perception, thought, and behaviour. The elusive and intangible 'latent' presence of Kautilya in modern Indian politics, according to him, can be explained through habitus, a sociological concept he borrows from Pierre Bourdieu which is the repository - 'carrier' or 'container' - of latent ideas that are 'forgotten' but efficacious. ${ }^{57}$ However, acknowledging the presence of Kautilyan thought (both implicit and explicit) is not enough. It is also important to understand how it has led to reinforcing state violence, gendered state practices, and reproducing power relations. In doing so, this section shall extend the idea of latent presence of Kautilya to the conflict setting of Kashmir and show how masculine elements found in Kautiyan thought are upheld and preserved by the contemporary actions of the security state in Kashmir.

The nexus of the Brahmanical and Kshatriya masculinity in Arthashastra, as discussed earlier, is clearly visible in the approach of the Indian state towards the conflict situation in Kashmir. The Kshatriya aspect of masculinity of the Indian state is generally associated with the stereotype of man acting as a warrior, "defender[s] of freedom, honour, and homeland and of their women." 58 In other words, in a conflict situation, the ideals of Kshatriya masculinity are most evident in the behaviour of militarised men, structures, and institutions. This is because militarization is a process that emphasizes the use of coercive structures and practices such as obedience, use of force, discipline and hierar-

55 Thomas B. Hansen, "Recuperating Masculinity: Hindu Nationalism, Violence and the Exorcism of the Muslim 'Other". Critique of Anthropology. Vol. 16, No. 2, 1996, p. 137-172.

56 Subrata K. Mitra and M. Liebig and, Kautilya's Arthashastra: An Intellectual Portrait: The Classical Roots of Modern Politics in India, Frankfurt, Nomos Verlagsgesellschaft, 2017.

57 Michael Liebig, "Kautilya’s Relevance for India Today..

58 Jamie Munn, “The Hegemonic Male and Kosovar Nationalism, 2000-2005”. Men and Masculinities, Vol. 10, No. 4, 2007. 
chy. ${ }^{59}$ It is through an adoption of such militaristic values that men, states, organisations, and groups can prove their manliness. This is premised on the process of gendering where men are expected to conform to all the ideals of masculinity that are denuded of any feminine qualities, since any male behaviour reflecting femininity is considered a sign of weakness.

Such Kshatriya masculine norms are most visible in the danda approach used to punish people with 'anarchic tendencies'. This is done through extensive training strategies and methods used by the Indian army for its counterinsurgency operations. The Indian army and other military forces involved in the counter insurgency operations go through vigorous training in bitter conditions in order to prepare their cadre and to make 'men out of boys' to fight against the militants. Indian troops are vigorously trained to operate in mountainous terrains, conduct cordon and search operations, cross rivers, crawl under barbed wires, climb up walls made of tires, walk on ropes, and cross extremely narrow bridges and so on. Narratives of 'jawans' (young soldiers) show that both physical and arms training makes them feels more 'manly'. The physical discipline along with the violent training helps instil feelings of 'bravery' and 'courage'. They are taught to work hard with determination in order to serve and protect 'mother India' by fighting against its enemies. The army training also involves shouting aloud slogans of victory, bravery, and determination to motivate themselves. Another dimension of the Kshatriya masculinity reflected in the danda approach is the display of the physical prowess and violence of army and other state armed forces through the use of modern weaponry as a strategy for counter insurgency operations. Along with the use of advanced guns to fight the militants, the use of pellets, firing and tear gas to counter protests by the stone pelters is an effective strategy to create fear in the minds of locals.

Apart from the physical aspect of Kshatriya masculinity, which is also be present in other military practices around the world, the state also uses manipulative techniques representing Brahmanical masculinity, such as 'sama', 'dana', 'danda' and 'bhed' (explained before) to appropriate the nationalist discourse. For instance, through its operation sadbhawana (goodwill), the state armed forces portrayed a softer image of itself in the past to win the confidence of locals.

\section{Jawan aur Awam, Aman hai Muqaam60 (The soldier and the people, peace is the destination)}

This operation was started by the 15 Corps of the Indian army in 1998 as a "unique humane initiative undertaken by the Indian Army in the J\&K state to address the aspirations of people affected by the scrouge of terrorism, sponsored and abetted by Pakistan" (Indian Army website) ${ }^{61}$ and runs alongside the ongoing militarized violence, even in contemporary times. This operation propagates "winning the and minds of the people of Kashmir through compassion and goodwill." As part of this operation, Indian army officers since 2010 have sought to help their soldiers learn local language and customs so that they can better reach out to the public. In the words of an army general, 'Heart is a weapon', which

59 Anuradha Chenoy, "Militarization, Conflict and Women in South Asia" in L.A Lorentzen and Jennifer Turpin (eds.), The Women And War Reader. New York: New York University Press, 1998.

60 More information on Operation Sadhbhavna is available on the Indian Army website: https://indianarmy. nic.in/Site/FormTemplete/frmTempSimple.aspx?MnId=HEPwWEmrREvm6FAQs8JeSg==\&ParentID=e / J4wC4Y24PIM3XSMyQDWg== (accessed on 14/03/21).

61 Ibid. 
indicates a contradictory approach towards managing and reaching out to the people. According to Bukhari, 'the army's expanding armoury now includes new weapons like the heart, culture, religion, living standards, quality of life, and the sensitivities of the people.62 Such new tactics have come in response to the changing nature of resistance mobilisation in Kashmir that has acquired a new moral dimension over the state forces since 2010. Some billboards and the army website include pictures of soldiers holding hands with Kashmiri people and guiding them towards the Haj pilgrimage or helping them during the floods in $2014 .{ }^{63}$ All these attempts represent the 'sama' and 'dana' approach that aim at building friendly relations with locals who have carried angry sentiments against the Indian state for decades.

Unlike the traditional understanding of 'bhed' as a divide-and-rule strategy, it can be understood in the context of Kashmir as psychopolitical attempts by the state to create fear and hegemonize its position in the conflict. This is done through sloganeering and graffiti. The graffiti on the walls and hills, for instance, is a sight that cannot be missed in Kashmir. A large slogan 'Ajeet hain abheet hain' (We are victorious and we are fearless), which was engraved on Zabarvan hill in Srinagar, is a deliberate display of the idealized masculine characteristics such as victory, bravery and courage of the Indian army. Two explanations may be offered. This graffiti may be characterized as Chaffee describes a 'territorial demarcation explanation' or it can be understood through 'psychopolitical' and 'political intimidation' explanations. ${ }^{64}$ The territorial demarcation explanation is extended to include all the slogans and graffiti that symbolically demarcate a particular area as controlled or liberated, rightfully belonging to a specific group or a nation. Similarly, the huge graffiti by the army on the hill can be explained as a territorial demarcation that displays the fact that Kashmir is controlled by the Indian state. Both these explanations throw light on characteristics such as 'territorial' and 'political intimidation' that symbolize attempts to prove masculine dominance.

Similarly, a slogan written on a state camp that reads 'Get them by their balls, hearts and minds will follow' ${ }^{65}$ strongly indicates the use of force or privileging of violence and glorifies aggression against enemies. More importantly, it fully conforms to the idea of an idealized masculinity where being a man signifies an innate characteristic of showing aggression and using force and violence. Another important aspect of this phrase is the use of the word 'balls', which is essentially directed at the control of the masculinity of the enemy, the insurgents in this case. For it is through the destruction of the 'balls' that the enemy shall lose all his manliness and come under the control of the army. Hence, controlling the enemy's masculinity is the key to their subjugation and subordination. It is interesting how the message in this slogan is completely contrary to the message of Operation Sadhbhawna (goodwill) discussed before.

A number of other slogans and symbols found at the army camps, written on the weapons and on the billboards suggest the attempts to portray the Indian state as the ideal masculine warrior. For instance, the Rashtriya Rifles, a specially created unit of the Indian army, trained for the Counter Insur-

62 Parvez Bukhari, “Kashmir: India's Pyramid of Unchanging Policy Posture”, Conveyor, Vol.3 No.2, 2011.

63 These pictures were seen on the billboards in and around Srinagar. Also, on the Indian army website.

64 Lyman G.Chaffee, Political Protests and Street Art: Popular Tools for Democratization in Hispanic Countries, United States of America: Green Wood Press, 1993.

65 A picture of a state camp in South Kashmir in 2008 by Javed Dar in Conveyor, Vol.3, No. 2, April 2011, p. 35. 
gency (COIN) operations earlier sought to establish its dominance through invocation of masculinist messaging:
Hathiyaar toh shouk se rakhte hain hum
Baaki khauf ke liye naam hi kaafi hai
(We just hold weapons as a hobby,
but our name is enough to create fear. $)^{66}$

The discussion of training methods and other strategies used by the state armed forces shows how the security state is intimately tied with the masculine elements of Kshatriya and Brahminical masculinity present in the Kautilyan thought. However, the connection between the state and masculinity is constantly reinforced in order to sustain its dominance. In this regard, it is important to note that cultural representations are extremely important in understanding how the ties between state military and masculinity are strengthened and how its hegemonic masculinity is forged and secured. Furthermore, mainstream Indian media and popular culture play a significant role in perpetuating the association of the Indian armed forces with the ideal masculine characteristics of heroism, patriotism, violence, aggression and so on. Especially important are Bollywood movies made about wars that depict the Indian army, which serve as medium through which to idealize the army's masculine character and reproduce it as a 'natural' phenomenon. As in other parts of the world, such depictions help justify state violence and encourage young men from different parts of the country to join the army or idolize the men in army.

Practices and performances often tell stories of the gender codings of states more effectively than the assumed masculine projections on the state. There are several other state practices in the Kashmir conflict that indicate the subtle exercise of different masculinities that can be a part of a separate project altogether. More importantly, through the example of Kashmir, this paper has tried to highlight the significance of moving beyond an exclusive critique of Western masculinity found in Westphalian notions of the state and assess instead the hybrid forms (both Western and nonWestern) of masculinities that the state may wield to exercise power. This helps in not only expanding our understanding of state as a hybrid performative actor, but also contributes to our understanding of how non-Western local traditions contribute in constructing gendered states. Finally, it is important to state here that, although the paper shows the connections between masculinities and state practices, it refrains from using 'hyper masculinity', 'military masculinity', or 'hegemonic masculinity' in a monolithic manner to denote the violence of all men. This is because the comfortable use of masculinity in conflict-affected contexts leads to the reproduction and reinforcement of these terms "without relating them to their respective local, historical, political and socio-economic contexts". ${ }^{67}$ There are multiple masculinities in conflict that often get overlooked in research due to our focus on military/militarized violence. Even within the military masculinities, there are gender hierarchies that are often rendered invisible due to this focus on the linkage between violence and military/militarized men.

66 A number of training practices and slogans of Rashtriya Rifles were earlier available on their facebook page: https:// www.facebook.com/IndianArmyrashtriyaRifles accessed on 7/04/2015.

67 Henri Myrttinen, L. Khattab \& J. Naujoks, "Re-thinking Hegemonic Masculinities in Conflict Affected Contexts", Critical Military Studies. Vol. 3, No. 2. 2016, p. 103-119. 


\section{Making Connections}

The security state in Kashmir, like other states in other conflict-affected contexts, portrays a secular, patriotic, and 'bound by national interest' imagery. However, its practices in conflict embodied through repressive counter-insurgency operations, its attempts at creating goodwill and other subtle indicators such as graffiti/engravings, slogans and cultural representations, all point towards a tacit hybrid presence of colonial mimicry, postcolonial anxieties, and masculine elements in Kautilyan thought. How post-colonial nation states enact their own forms of coloniality is based on multiple factors, not only the mimicry of the West. The reference to Kautilyan thought in the paper is not simply about acknowledging the relevance of Indian political philosophies in IR, but instead revealing how these political philosophies have contributed towards similar reproductions of colonial and gendered state behaviour.

From a disciplinary perspective, the objective of this paper was to show that adding or amplifying the presence of non-Western approaches in IR is not enough. Using a critical lens to show how non-Western political philosophies also result in exclusionary and discriminatory state practices is equally important. The challenge to Western knowledge bias in IR is of crucial importance, but driving all focus on its critique through indigenous vantage points results in overlooking the nuances in the operation of power. The obsessive need to incorporate local political traditions is sometimes counter-productive to the critical perspective in international politics. In this context, the paper has also tried to show that the use of a feminist and a critical masculinities' lens offers an intersectional framework, enabling a more grounded critique of both Western and non-Western approaches. In doing so, it also facilitates a move beyond the binaries of Western/non-Western and global North/South.

Finally, this paper, offers an avenue for discussing the hybridity and connectedness of Western and the non-Western approaches to understanding power relations and proposes to think beyond just claiming a 'global south' space in the IR discipline: to divert energies towards challenging the gendered and unjust practices dominating international politics. Both Western and non-Western realist political traditions have problematic gendered characterizations that need to be constantly questioned. Adopting a feminist/ critical masculinities standpoint further highlights the embedded power relations in state practices that are pervasive in implicit ways, especially in conflict-affected contexts. There is a need to put anti-colonial thought in the centre-stage of theorization. Furthermore, an interdisciplinary approach, instead of a fixation on IR per se, and an eclectic methods approach may be more productive in building competent critical approaches.

\section{Bibliography}

Acharya, Amitav and Barry Buzan (2009). Non-Western International Relations Theory: Perspectives on And Beyond Asia. New York, Routledge.

Akbar, M.J (2002). Kashmir: Behind the Vale. New Delhi, Roli Books Pvt. Ltd.

Anand, Dibyesh (2007). "Anxious Sexualities: Masculinities, Nationalism and Violence". The British Journal of Politics and International Relations. Vol. 9, No. 2. Available at: https://journals.sagepub.com/doi/full/10.1111/j.1467856x.2007.00282.x. (accessed on 10/02/2021).

Bajpai, Kanti (2003). "Indian Conceptions of Order and Justice: Nehruvian, Gandhian, Hindutva and Neo-Liberal” R. Foot, et al (ed.), Order and Justice in International Relations. New York, Oxford University Press, p. 236-261. 
Baweja, Harinder (1992) “Kashmir: A Calculated Gamble”. India Today.

Behera, Navnita C (2007). “Re-imagining IR in India”, International Relations of the Asia-Pacific. Vol.7, p. 341-368.

Bhambra, Gurminder K (2010). "Historical Sociology, International Relations and Connected Histories”, Cambridge Review of International Affairs, Vol. 23, No. 1, p. 127-143.

Bilgin, Pinar (2016). ““Contrapuntal Reading” as a Method, an Ethos and a Metaphor for Global IR”, International Studies Review, No. 18, p. 134-146.

Bukhari, Parvez (2011). “Kashmir: India’s Pyramid of Unchanging Policy Posture”, Conveyor, Vol.3 No.2.

Butler, Judith (1997). Excitable Speech: A Politics of Performative. New York, Routledge

Capan, Zeynep Gulsah (2016). Rewriting International Relations: History and Theory Beyond Eurocentrism in Turkey. London and New York, Rowman and Littelfield.

Chacko, Priya (2012). Indian Foreign Policy: The Politics of Postcolonial Identity from 1947-2004. London and New York, Routledge.

Chaffee, Lyman G (1993). Political Protests and Street Art: Popular Tools for Democratization in Hispanic Countries. New York, Green Wood Press.

Chakravarti, Uma (1988). "Saffronising the Past: Of Myths, Histories and Right Wing Agendas", Economic and Political Weekly, Vol. 33, No. 5, p. 225-232.

Chenoy, Anuradha M. (2002). Militarism and Women in South Asia. New Delhi, Kali for Women.

Chenoy, Anuradha M. (1998). "Militarization, Conflict and Women in South Asia”, L.A Lorentzen and Jennifer Turpin (eds.) The Women And War Reader. New York, New York University Press.

Chowdhury-Sengupta, Indira. (1995). "The Effeminate and the Masculine: Nationalism and the Concept of Race in Colonial Bengal”, Peter Robb (ed)., The Concept of Race in South Asia. New Delhi, Oxford University Press.

Chimni, B.S. (2004). International Law and World Order: A Critique of Contemporary Approaches. New Delhi, Sage Publications.

Dasgupta, Chandrashekhar (2002). War and Diplomacy in Kashmir: 1947-48. Delhi, Sage.

Duriesmith, David (2018). "Hybrid Warriors and the Formation of New War Masculinities: A Case Study of Indonesian Foreign Fighters", Stability: International Journal of Security and Development, Vol. 7, No.1.

Habibullah, Wajahat. (2008). My Kashmir: Conflict and the Prospects of Enduring Peace. Washington, United States Institute of Peace Press.

Harshe, Rajen (ed.) (2004). Interpreting Globalisation: Perspectives in International Relations. New Delhi, ICSSR and Rawat Publications.

Hansen, Thomas B. (1996). "Recuperating Masculinity: Hindu Nationalism, Violence and the Exorcism of the Muslim 'Other”, Critique of Anthropology. Vol. 16, No.2, p. 137-172.

Henry, Marsha et al. (2009). "Positionality and Power: The Politics of Peacekeeping Research”, International Peacekeeping, Vol. 16, No.4, p. 467-482.

Inayatullah, Nayeem and David Blaney (1996). "Knowing Encounters: Beyond Parochialism in International Relations Theory”, Yosef Lapid and Friedrich V. Kratochwil (eds.) The Return of Culture and Identity in IR Theory, Boulder, CO: Lynne Rienner Publishers, p. 65-84.

Koshy, Ninan (2005). "Nuclear Weapons and India's Foreign Policy”, Rajen Harshe and K.M. Seethi (eds.), New Delhi, Orient Blackswan.

Liebig, Michael (2013). “Kautilya's Relevance for India Today”, India Quarterly: A Journal of Indian Affairs, Vol.69, No. 2, p. 99-116.

Manchanda, Rita (2001). Women, War and Peace in South Asia: Beyond Victimhood to Agency. New Delhi, Sage.

Mehta, Pratap Bhanu (2005). "SAARC and the Sovereignty Bargain”, Himal South Asian, November-December Issue, p. $17-21$.

Mena, Ferran P. (2020). “The Trap of Diversity: What Constitutes 'Non-Western IR Theory'?”, E-International Relations. Available at: https://www.e-ir.info/2020/05/08/the-trap-of-diversity-what-constitutes-non-western-ir-theory/ (accessed on 14/04/21).

Mitra, Subrat K. and Michael Liebig, Michael (2017). Kautilya's Arthashastra: An Intellectual Portrait: The Classical Roots of Modern Politics in India. Frankfurt, Nomos Verlagsgesellschaft. 
Munn, Jamie (2007). “The Hegemonic Male and Kosovar Nationalism, 2000-2005”, Men and Masculinities, Vol. 10, No. 4. Myrttinen, Henri et al. (2016). "Re-thinking Hegemonic Masculinities in Conflict Affected Contexts”, Critical Military Studies, Vol. 3, No. 2, p. 103-119.

Nandy, Ashis (1983). The Intimate Enemy: Loss and Recovery of the Self Under Colonialism. New Delhi, Oxford University Press.

Nilan, Pam. and Carles Feixa (2006). "Introduction: Youth Hybridity and Plural Worlds", Pam Nilan and Carles Feixa (eds.) Global Youth? Hybrid Identities, Plural Worlds, Oxon, Routledge, p. 1-13.

O'Hanlon, Rosalind (1997). "Issues of Masculinity in North Indian History: The Bangash Nawabs of Farrukkha”, Indian Journal of Gender Studies, Vol.4, No.4, p.1-19.

Olivelle, Patrick (2014). King, Governance and Law in Ancient India: Kautilya's Arthashastra-A New Annotated Translation. New Delhi, Oxford University Press.

Osuri, Goldie and Ather Zia (2017). "Kashmir and Palestine: Itineraries of (Anti) colonial Solidarity”, Identities: Global Studies in Culture and Power, Vol. 27 No.3, p. 339-356.

Pandit, Idrisa (2019). “The 'Israel Model': The fragile Paradise of Kashmir faces an Existential Threat”, Middle East Eye, December 3.

Parashar, Swati (2018). "Competing Masculinities, Militarization and the Conflict in Kashmir”, International Feminist Journal of Politics (IFJP), Vol. 20, No. 4, p. 663-665.

Pasha, Mustapha K (2011). "Western Nihilism and Dialogue: Prelude to an Uncanny Encounter in International Relations", Millennium -Journal of International Studies, Vol. 39, No.3, p. 683-99.

Peterson, Spike V (1992). Gendered States: Feminist Revisions of International Relations Theory. Lynne Rienner.

Sarkar, Benoy K (1919). “The Hindu Theory of International Relations”, American Political Science Association, Vol. 13, No. 3, p. 400-414.

Said, Edward (1978). Orientalism. New York, Vintage Books.

Schulz, Philipp (2020). Male Survivors of Wartime Sexual Violence: Perspectives From Northern Uganda. Oakland, University of California Press.

Seth, Sanjay (2011). "Post-Colonial Theory and the Critique of International Relations", Millennium: Journal of International Studies, Vol. 40, No. 1.

Shani, Giorgio (2008). “Toward a Post-Western IR: The Umma, Khalsa Panth, and Critical International Relations Theory”, International Studies Review, Vol.10, No.4, p. 722-34.

Shilliam, Robbie (2009). “The Enigmatic Figure of the Non-Western Thinker in InternationalRelations”, Antepodium: Online Journal of World Affairs, Victoria University of Wellington.

Sinha, Mrinalini (1999). "Giving Masculinity a History: Some Contributions From the Historiography of Colonial India”, Gender and History, Vol. 11, No.3, p. 445- 460.

Sivakumaran, Sandesh (2007). "Sexual Violence against Men in Armed Conflict”, European Journal of International Law, Vol. 18 , No. 2, p. 253-276.

Suleri, Sara (1992). The Rhetoric of English India. Chicago, University of Chicago Press.

Touquet, Heleen. and Ellen Gorris (2016). "Out of the Shadows? The Inclusion of Men and Boys in Conceptualizations of Wartime Sexual Violence”, Reproductive Health Matters, Vol. 24, No. 47, p. 36-46.

Vanaik, Achin (2004). "Globalization and international relations", Achin Vanaik (ed.),Globalization and South Asia: Multidimensional Perspectives. New Delhi: Manohar.

Whitehead, Andrew (2007). A Mission in Kashmir. New Delhi, Penguin.

“Land transfer to Hindu Site Inflames Kashmir's Musims”. New York Times, June 28, 2008. 